\title{
Student Perceptions of the Fairness of Video Presentation Grading in the Online EFL Classroom
}

\section{Copeland, Charles ${ }^{1}$}

\begin{abstract}
This qualitative case study, which employed thematic analysis, explores student perceptions about the fairness of grading video presentations in an online EFL Korean classroom. The study surveyed 145 students about their attitudes towards the fairness of grading for video presentations using three open-ended questions. To better understand the students' thoughts, they were asked what most affected the fairness of grading live versus video presentations. It found that students believed that the use of video presentations in the required classroom was fair. The students cited a clear, understandable rubric, hard work resulting in the deserved grade, the best material could be submitted, the video could demonstrate ability without nerves, and the teachers' grading as reasons the grading was deemed fair. There were also some negative perceptions related to the fairness of grading. The two registered were using cheats and not having a fair playing field in terms of technology. The study also found that the main factors affecting video versus live presentations were the fear of live presentations, preparation time, technology use, and the teachers' grading. The results from the survey indicated that student-produced video presentations should be considered in the future.
\end{abstract}

Keywords: student created video presentations, anxiety, motivation, $21^{\text {st }}$-century skills, fairness Applicable level: tertiary

\footnotetext{
${ }^{1}$ Corresponding author, Foreign language teaching assistant professor, College of Liberal Arts, Dankook University, Jukjeon Campus 152 Jukjeon-ro, Suji-gu, Yongin, 16890, Korea (E-mail: dankookclass@gmail.com)

Received: August 24, 2021

Revised: November 19, 2021

Accepted: November 21, 2021

Copyright: (C) 2021 The Society for Teaching English through Media (STEM)

This is an open access article distributed under the terms of the Creative Commons

Attribution Non-Commercial License (http://creativecommons.org/licenses/by-nc/4.0), which permits unrestricted non-commercial use, distribution, and reproduction in any medium, provided the original work is properly cited.
} 


\section{INTRODUCTION}

While teaching English as a foreign language (EFL) at a South Korean university during the second semester of 2020 , the researcher was interested in determining what elements of the online classroom could translate to the regular classroom when the Coronavirus pandemic subsided. One element that the researcher thought might be usable in the future were video presentations. Before the pandemic, the general education curriculum utilized in-classroom presentations. The researcher observed that some students became so nervous while performing a presentation that they shut down entirely and could not finish it. In extreme cases, the researcher noted that students did not come to class when the live presentations were being performed or dropped the class. The fear of public speaking, or speaking anxiety, referred to as glossophobia, is one of the most common phobias (Dansieh, Owusu, \& Seidu, 2021). The researcher noticed that nervousness in the video presentations during the pandemic semester seemed lessened than in previous semesters when students presented in front of the classroom.

The researcher's concern was whether students would perceive the replacement of in-person presentations with video as a legitimate alternative. The researcher noticed that students were keenly interested in how the presentations were graded. Fairness was one issue that students deemed important. Wallace (2018) noted that fairness is a subjective construct based on cultural definitions. Babaii and Adeh (2019) concluded that an assessment could not be considered fair unless "the majority of the examinees think otherwise" (p. 63). Therefore, student opinions need to be gauged to determine if video presentations are a fair classroom practice.

The use of video versus in-class presentations could produce other benefits for the students. Student-created video presentations can offer $21^{\text {st }}$-century skills, which can help boost language levels (Kulsiri, 2018; Naqvi \& Al Mahrooqi, 2016; Yeh, 2018). The students also had to utilize reflective thinking (El-Garawany, 2017; Hallemans, 2021) when they decided if their video was good enough to turn in or not based on the posted rubric. The study examines the following questions: 1. Do students feel that the grading of video presentations was fair? 2 . Why do students feel that presentations are or are not fair? 3. What factors do students perceive as most affecting the fairness of video versus live presentations?

\section{LITERATURE REVIEW}

Teachers used video presentations to good effect before the pandemic. Students were able to improve their language skills through reflective practices. Implementing a video presentation also led to gaining $21^{\text {st }}$-century skills. Researchers have not reported high levels of anxiety in video presentations as often as those performed live. There was also an increase in the student motivation to learn (Ahmad \& Lidadun, 2017; Mali, 2018; Naqvi \& Al Mahrooqi, 2016; Yeh, 2018).

\section{Building EFL Skills Through Video Presentations}

Students reported that their English level had improved through video presentations (Cowie \& Sakui, 2018; ElGarawany, 2017; Kulsiri, 2018; Naqvi \& Al Mahrooqi, 2016; Santhi, Suherdi, \& Musthafa, 2019; Stanley \& Zhang, 2018). Huang (2021) recorded statistically significant higher test scores from students after completing video tasks in the classroom. Mali (2018) attributed part of the language gains observed to the opportunity for students to "repetitive learning behaviors they did in completing the project" (p. 15). Hallemans (2021) found that students spent almost as long recording and rerecording their video presentations as they did in preparation. The students watched themselves and reflected on whether the material was good enough to turn in (Hallemans, 2021). El-Garawany (2017) concurred that having video presentations was a reflective practice. Cowie and Sakui (2018) stated that the lower proficiency students benefitted more from the video project than the traditional classroom. Students were better in their body language, facial expression, and eye contact in video presentations because they could see themselves and adjust.

Other benefits reported from using video presentations in the classroom included creativity (Ahmad \& Lidadun, 2017), positive learning attitudes (Huang, 2021), and improved engagement (Stanley \& Zhang, 2018). Ahmad and 
Lidadun (2017) observed students using different methods to complete the video presentation assignment, including varied delivery styles and attractive visual aids. This variety showed creativity from the students in making their video presentations. Huang (2021) found that all 65 of the students he interviewed had a positive perception of the video projects conducted in the class. Students' reasons for these sentiments included digital media production skills, communication with each other, and multiple proficiencies. Stanley and Zhang (2018) noted improved engagement through the use of video presentations. One student responded, "Creating the video really made you learn the subject, while watching others' videos made sure that I would keep tuning in every week" (Stanley \& Zhang, 2018, p. 13). Yeh (2018) noted that the video process aided students in garnering "passion, enthusiasm, and excitement" (p. 34) for the language as well as local cultural learning.

\section{Building $21^{\text {st }}$-Century Skills Through Video Presentations}

Another benefit of using student-produced videos, which is elucidated in previous literature, is building skills necessary in the 21 $1^{\text {st }}$-century (Hafner, 2014; Huang, 2021; Kulsiri, 2018; Naqvi \& Al Mahrooqi, 2016; Yeh, 2018). Huang (2021) stated that the skills the students learned helped meet the language learning goals and built skills needed in the $21^{\text {st }}$-century job market and would be helpful with solving real-world problems that might arise in the future. Hafner (2014) concurred, stating that student-produced videos helped language learning as well as the chance to "practice the important $21^{\text {st }}$-century skill of orchestrating semiotic resources in various modes in order to make meaning" (p. 682). The use of information and communications technology (ICT) tools was beneficial to language learning and should be added to the English classroom, which video production can accomplish (Kulsiri, 2018; Naqvi \& Al Mahrooqi, 2016; Yeh, 2018).

However, some concerns arose from the use of technology in the EFL classroom. Lee (2019) found two barriers to video production in the EFL classroom: difficulties producing and uploading videos via non-mobile devices and the software/hardware problems that could arise from the project. Cowie and Sakui (2018) raised another concern about teaching technology in the student's second language as a threshold level of English might be necessary. Santhi et al. (2019) found that 13 out of 35 students had difficulties creating and editing the videos, indicating how technologically challenging the project could be. Another issue students faced was how to send their large video files through email (Miskam \& Saidalvi, 2020). Mali (2018) stated that there were numerous technological hurdles for the students and that teachers would have to help the students overcome them. There was also the issue with the teacher having difficulties with the technology or having negative attitudes towards its use in an EFL classroom (Cowie \& Sakui, 2018; Soifah, Jana, \& Pratolo, 2021).

\section{Avoiding Anxiety Through Video Presentations}

According to Krashen (2009), anxiety is anathema to second language acquisition, raising a student's affective filter and blocking language learning. Bandura (1983) theorized that "People who judge themselves to be inefficacious in managing potential threats approach such situations anxiously, and the experience of disruptive arousal, in turn, lowers their sense of efficacy that they will be able to perform skillfully" (p. 466). Dörnyei and Ushioda (2021) listed the anxiety from fear of failure as one of the significant detriments to student motivation. However, anxiety plays an important role in oral presentations. Grieve, Woodley, Hunt, and McKay (2021) noted that fear of live performances could hurt a student's university experience and be a factor in mental health and wellbeing issues. Dellah, Zabidin, Nordin, Amanah, and Atan (2020) found that student English proficiency level substantially affected the anxiety felt when speaking. Elements for fear of speaking included: fear of making mistakes, fear of people laughing at them, and fear of eye contact (Fadlan, 2020; Sulastiani, 2020).

In the classroom, teachers have used presentations as a way to teach speaking in the EFL setting. With these activities, Arifin (2017) reported that "many students place speaking presentations ahead of death itself in their relative ranking of fears" (p. 37). Amalia and Ma'mun (2020) found 68\% of the students in the survey felt embarrassed speaking in front of a class during a presentation, and $71 \%$ were worried about making mistakes. However, while some student video presentation research mentioned anxiety, it was not prevalent. This reduction of researchers reporting anxiety indicates a potential benefit of using video presentations in the EFL classroom. 


\section{Building Motivation Through Video Presentations}

Motivation is an essential facet of any foreign language classroom (Dörnyei, 1994; Lumsden, 1994; Tuan, 2012). Tuan (2012) found that students were not motivated enough and depended on the teacher to develop motivating tasks to help them learn. Yeh (2018) concluded that video presentations got students involved, which increased the motivation to learn the target language. Ahmad and Lidadun (2017) noted that video presentations engaged students, which led to increased motivation. Mali (2018) explained that when teachers can incorporate user-friendly technology, like video presentations, to attract attention builds motivation. Naqvi and Al Mahrooqi (2016) concurred that studentcreated videos could lead to engagement and increase student motivation. Hallemans (2021) noted that the students appeared to be motivated by using video presentations. One of the students in the study wrote that making a video presentation took more time, "but that is a process for study, not a waste of time" (p. 239).

\section{Building Fairness in Assessment Through Video Presentations}

Fairness is a subjective construct that cannot be separated from the culture of the test taker (Wallace, 2018). However, an assessment is fair if the participants believe it (Babaii \& Adeh, 2019). Wallace (2018) broke fairness into four segments: distributive, procedural, interactional, and informational. Distributive fairness is the idea that procedures throughout the process are equal for all participants. Procedural fairness refers to the "methods used to assign grades or award scores on a test" (Wallace, 2018, p. 1053). Rubrics can help align learning with grading and let the learner know what performance levels are needed for a given grade (Brookhart, 2018). Wallace (2018) defined interactional fairness as that the teacher "communicates with the test taker in a fair, respectful manner" (p. 1054). Anderson and Fujishima (2021) wrote that in an online setting, the rubric "can function as a valuable communicative tool between educators and learners" (p. 16). Informational fairness relates to the procedures being explained and individual feedback being given promptly to each test taker (Wallace, 2018).

\section{METHOD}

\section{Participants}

This study took place at a mid-sized university in South Korea. A total of 145 students participated in the study. The participants were predominately first-year second-semester students enrolled in a non-major course required for graduation. The survey was available to eight sections of the course taught by two different teachers. The two teachers that participated included the researcher and one other native English-speaking professor at the university. Both teachers had more than ten years of experience teaching at the university level when the questionnaire was administered. Each professor taught four of the sections that participated. Seven of the sections contained intermediate-level students with a total enrollment of 250 students. The final section was made up of beginner language learners, which consisted of 12 students. The level was determined by an English proficiency test similar to the TOEIC administered before enrollment at university. The university defined the beginner level as students who scored 400 or lower on the test. Those students with a score of 401-700 were placed in the intermediate level.

\section{Procedures}

The class was the second of the required courses and focused on presentations in English. Both teachers whose students were involved with the study ran their classrooms in a similar manner. Due to Coronavirus, the courses were held online following the university COVID-19 protocols. The teachers had the students record their presentations, upload them to YouTube, and then submit the link to the teacher and the other students through their learning management system (LMS). The students were required to video from head to knees to practice presentation techniques like body language and gesture. 
The textbook was divided into seven units. The initial unit was an introduction to presentations and lasted one week, which consisted of two classes. The other six chapters were broken into four classes each. The first class was devoted to activating background knowledge and brainstorming on the topic for the unit. The second class consisted of the organization of the presentation, including the introduction, body, and conclusion. The third class delved into presentation skills and tips. The final session for each unit was when the presentation was due. There were seven presentations in each class. Each student was required to perform, record, and upload five shorter presentations about one minute in length. The last two presentations were at the midterm and final and were longer. One teacher had them at three and four minutes respectively and the other at two and three minutes.

The videos were graded using a rubric that included grading points taught throughout the course. The grading points included language, organization, presentation technique, and time were considered (see Appendix 1). The teachers explained the rubric and posted the checklist in the LMS to be used while making their videos.

\section{Data Collection}

Students completed the survey through Google Forms. At the end of the semester, the participating teachers posted the link to the study in the classroom LMS. The students had the chance to respond during the last two weeks of the semester. The students were assured that responses were anonymous and voluntary. The survey collected no identifying information. Each student answered three open-ended questions related to the fairness of grading video and live presentations (see Appendix 2).

The questions used both English and Korean, the student's first language, to ensure they understood what they were being asked. The survey instructed students to respond in English or Korean. The researcher had responses in Korean translated to English before analysis. A total of 28 students responded in Korean, and the other 117 wrote in English. A native Korean who was also a teacher of English translated the original questions and student responses.

A total of 145 students responded to the survey. The responses to the three questions ranged from single-word answers to well-developed paragraphs. The longest response was 164 words in length. A total of 22 students wrote multiple sentences in response to the questions. A total of 90 students replied with a single answer with a reason why often in a complete sentence. The final 33 students responded with a single phrase or word to answer the questions. Students who answered "I don’t know" for one question are included in this group.

\section{Data Analysis}

The study was a qualitative case study that utilized thematic analysis to analyze the data. The responses to the survey were downloaded from Google Forms and analyzed using thematic analysis. Braun and Clarke (2012) segmented thematic analysis into six stages: getting familiar with the data, generating codes, searching for themes, reviewing themes, defining themes, and producing a report. The researcher read through the generated data to get a general understanding of what the participants had written. During the second reading, the responses received codes based on what had been written. The researcher went through all of the codes and combined and grouped similar thoughts into themes. The themes were reviewed again organized into the final grouping used in the paper. Student comments which best characterized each theme were selected before being crafted into the final results.

\section{RESULT}

The students were asked three questions about student attitudes towards using recorded presentations as a primary source of grading for the course and how this affected fairness in grading in a required EFL classroom. The first question was related to the fairness of using YouTube videos as presentations for the class. Out of the 145 students who responded to the survey, 130 students, or $89.7 \%$, believed that the grading generated using video presentations was fair. Eleven students felt that videos were not fair. Four students could not decide if it was fair or not. One of 
these students gave both sides, and three responded that they did not know. The second question related to what areas most affected the fairness when using videos as presentations. The third question related to what areas most affected the fairness of grading using videos versus live presentations. This section analyzes the responses to the final two questions and looks for trends in the answers.

\section{Fairness of Using YouTube Video Presentations in Class}

One hundred thirty students reported believing that the grading of videos was a fair way to run the required EFL class. The student responses fell into several categories. The students liked the feedback and rubric systems used by the two teachers. There was also a belief that hard work could pay off with a better presentation. The students liked that they could turn in the best possible video for grading. Then, students commented that they liked that the conditions were the same for everyone. Next, there were additional comments about not having to be nervous, using technology, better grading, and comparing with others by watching the videos. Finally, some students reported negative sentiments towards video presentations because of a belief that cheating was occurring and technical issues.

The most popular reason that students felt that videos were fair was that they were graded using a transparent and fair rubric with good feedback. Thirty-four students mentioned this in their explanations of why using video presentations was fair. Student 3 wrote, "I think it's fair. Because the professor gave detailed instructions on how the scores were reflected. Also, when giving feedback on the video, it informs the point where the score has been reduced and gives understanding." Student 20 agreed, "I think it's fair. This is because there are set standards, and if I look at the comments, I can understand the score. I think professor judging from the presentation fairly." Another point related to the rubric was brought up by Student 42 (translated), "The professor announced the evaluation method in advance and used the rubric, so it is reflected in the grade." Student 128 added the comment that it worked "because the standard of score is accurately appear before uploading." Based on the feedback and pre-published rubric, Student 68 felt more comfortable making a presentation. They stated, "The student can present according to the given rubric. Preparing for an online presentation is a student's ability. It's fair because the rubric." Therefore, a teacher who would like to use video presentations should make a strong rubric and explain the grading before the presentation. Then after the video is graded, give good feedback to help students improve for the next presentation.

The second most commented topic was that if students worked hard, they could earn their deserved score. A total of 17 students mentioned this area in their comments. Student 4 remarked, "You can see how hard I worked on the online video." Student 7 added, "A person who has prepared a lot can make a high-quality video without mistakes." Student 54 echoed these sentiments, "Students who have not really tried very hard and those who have put quite a lot of effort can be distinguished by video." Student 56 observed:

I think online presentation is fair because the tasks have been prepared by presenters and the video have been made by one-take. I think the times of recording as practice for presentations. The online presentations can show how the presenter can perform and has prepared.

Finally, Student 144 wrote, "Individuals have to make efforts to produce results." Therefore, using videos for presentations rewards students for spending time and effort working on their presentations. The next area mentioned by students was getting the highest quality work possible through using video presentations.

The third theme reported by 15 students was that using videos presentation allowed students to turn in the best video possible. Student 6 stated, "Each person submits a video that they think was the best shot." Student 31 agreed, "By preparing it in their most stable state, they are all able to make their perfect result as possible." Students liked being able to turn in the best possible video, as shown by Student 112, who wrote, "If you make a mistake, you can shoot again." Therefore, students believed that the product which got turned in was better if it was a video instead of a live presentation which aided the fairness in the grading.

The next area, which 14 students responded to as a reason for the fairness of using video presentations for grading, was that the conditions were the same for everyone. Student 35 stated, "It is not only for one person, but for everyone." Student 65 echoed this with the sentiment, "Everyone is given the same opportunity." Other students felt that the time allowed was necessary. Student 19 stated, "Everyone has the same amount of time to prepare their speech." 
Concerning time, Student 1 said, "I think the time to prepare the presentation is no less than live." There was also a segment of the student population who agreed that live and video had many similarities. Student 122 espoused this opinion with the statement, "There seems to be no difference between online and live."

Finally, there were some other comments made about students liking the use of video presentations. First, three students stated that they could show their ability without being nervous. Student 32 said, "Online presentations can fully represent one's ability without being nervous." Student 35 agreed, "Online presentations are much less stressful than live presentations, and can be carried out in a more comfortable state." A further two students commented about the use of technology in producing the videos, like Student 10, who said, "I think online presentation requires the technology to present its own online." Two students liked that the teacher could watch the video multiple times to determine a fair grade. Finally, one student thought using video presentations was good "because we can compare ourselves with students when watching their presentation" (Student 76). However, not all of the students were positive in their responses to using videos in the classroom.

Eleven students had negative responses about the fairness of using videos for presentations for homework and examinations. One student also discussed both positive and negative aspects. The first reason that three students reported was the possibility for a student to cheat on the video. Student 69 wrote, "There are some cheats. ex: After recording the video, record the voice file separately and insert it. or hide the script on the back of your phone." Student 54 was also concerned about reading or hiding the script to make it easier. Student 16 felt there were many tricks to making a video but did not go so far as to say that it was cheating. Two students were also worried about re-recording the videos. Student 30 stated, "I record videos until I meet the standards." However, scripts were not explicitly banned by the teachers who encouraged the use of note cards. The teachers also allowed the rerecording of the presentation.

Student 75 was worried about technology by replying, "equipment can affect the presentation." Other negative aspects reported in the survey responses include things not included in the grading standards, too different from a live presentation, prior experience, and feeling more confident with an audience.

\section{Elements Affecting the Fairness of Live Versus Video Presentations}

Several different elements are related to making live and video presentations. The most popular response was the fear of live performance. Second, students reported technology as a factor associated with making a presentation. Preparation time was the third most popular response to what effects presentations. The next factor affecting presentations was the teacher's grading. Finally, there were some other miscellaneous effects reported by the students. There were more than 145 responses because some students listed more than one reason (see Table 1).

The fear of live presentations was the main element affecting in versus video presentations. It was mentioned in some form by 67 students out of 145, or $46.2 \%$. Student 11 stated, "I think it's a fear of live performances. Even if I prepared hard, if I get nervous on the day, I can't make a good presentation." Student 18 was concerned that a live presentation might not allow them to reach their potential, saying, "The most effective factor is fairness in grading live. There is a huge psychological difference between presenting in front of people and presenting in front of the screen. The best online presenter may be poor presenter." Student 42 tried to highlight the reason for the nervousness, writing, "Live is given only one opportunity, which requires more effort than online and is also very tense. Therefore, it is highly likely that live broadcasts will make mistakes that can be avoided online." Student 54 added:

I think students can be very nervous when they make a presentation in a foreign language for the first time in front of students they see for the first time. Therefore, even students who have been good at presenting can stutter with nervousness, which can cause timeouts, staring at the ceiling, etc. to reduce scores. For this reason, I think that the fear of live presentation can undermine fairness as students have no experience in live presentation.

Student 56 stated, "fear of live performance effect the fairness of grading." Based on these comments, the fear of live performances was the central element in the effects of in-class versus video presentations. 
TABLE 1

Student Reported Elements Affecting Live vs. Online Presentations

\begin{tabular}{ccc}
\hline Element & Number & \% of Students \\
\hline Fear of live performances & 67 & 46.2 \\
Preparation time & 31 & 21.4 \\
Use of technology & 22 & 15.2 \\
Teacher's grading & 17 & 11.7 \\
Performance & 4 & 2.8 \\
Cheating & 2 & 1.4 \\
Differences between online and offline & 1 & 0.7 \\
Location to make a video & 1 & 0.7 \\
Long commute & 1 & 0.7 \\
Coronavirus & 1 & 0.7 \\
\hline
\end{tabular}

The second most discussed element affecting live and video presentations was preparation time, with 31 students mentioning it. Student 4 is mixed about the time spent working on the presentation with the comment:

It takes me two days to submit the video. It's hard, my legs hurt, and my throat is swollen. The online presentation is fair because it reflects my efforts because I get good grades for online presentation. It depends on whether you see effort or ability.

Student 31 (translated) concurred with the opinion:

The preparation time for the presentation is long. The best outcome you can prepare for is enough time; it seems to be the fairest way to evaluate it online because it excludes the inevitable situations such as tension, pronunciation, etc.

Student 105 also listed preparation time as the main element that affects the difference between online and live presentations with the statement, "Different from offline presentation, students can use much time to make presentation and this might very closely related to the quality of presentation."

The third major theme that developed from the student responses of factors affecting live versus online presentations was technology. Twenty-two students, or $15.2 \%$, responded that technology was a factor in the fairness of grading presentations. The students thought that technology was not only crucial to online presentations as Student 10 wrote, "I think that the technology part has a lot of influence when presenting in front of an audience, such as live." However, the central theme from comments about technology was the difficulties students encountered. Student 29 stated, "I think who doesn't have a computer or a laptop cannot prepare a presentation well than others who has." Student 2 opined, "Some of us have a Bluetooth mouse, and some of us hasn't. It's quite huge in presentation." Student 51 concurred with the opinion, "It is a bit hard to show my PowerPoint when doing online presentations." Other issues the students listed included "editing skill problems" (Student 66) and "network problems" (Student 107).

\section{CONCLUSION}

Students predominately felt that video presentations were a fair way to complete a required presentation class. Students liked the fairness of using video presentations because they thought their work reflected in the grade and could send in their best work. Related to this, students felt that they were not as nervous as they would have been, making the grading fairer. This factor is further reflected in the data when fear of live presentations is listed as the number one factor in the fairness between video and live presentations. This sentiment is backed by research on the effects of anxiety on language production (Bandura, 1983; Dörnyei \& Ushioda, 2021; Krashen, 2009). It would be advisable for teachers to consider anxiety as a factor related to the fairness of grading presentations and consider using student-created videos over live presentations, even when classes meet in person.

Students thought that they got a fairer grade because they were able to have the necessary time to create their best 
presentation. The students believed that the extra time allowed them to put forward their best work. They admitted that it was hard but liked seeing the effort and time invested in the presentation reflected in the grade they received. Some negativity related to a few students who felt cheating occurred when students recorded the video until they got it right. However, this type of sentiment was only reported by two out of 145 students. It is something to keep in mind but not a significant worry for the students. By re-recording their video presentations until they reached the goal, students were using reflective thinking (El-Garawany, 2017) by judging whether their presentations met the guidelines of the class. After returning to normalcy from Coronavirus in the coming months, this repetition and reflection about whether the video met the standards could benefit student English proficiency levels.

Technology was an issue for using student-created videos for a presentation class. The first issue noted was that not everyone had the same access to technology, whether it was connectivity or equipment. Other students felt that they did not have the tech skills necessary to complete the project. By working through these issues, students built $21^{\text {st }}$-century skills that could help them adapt to technology in the future, as was predicted in the literature (Huang, 2021; Kulsiri, 2018; Naqvi \& Al Mahrooqi, 2016; Yeh, 2018). Because there are some issues, teachers need to be prepared to help students when they have difficulties addressing any fairness issues in recorded presentations. Postpandemic, the technology the students had to utilize will continue to grow as an element of society.

The final reason to help build fairness was using a grading rubric and standards for grading that the students could easily understand. Both teachers participating in the survey used a rubric and checklist to help students know what was being graded in the class. They both published the rubric before the grading, so students knew what to expect. Based on this, it would be suggested that a teacher using video presentations be as transparent as possible about the assessment of the videos before assigning them. This takeaway was true before the pandemic but magnified because using a clear rubric was crucial in communicating with students in a distance learning setting (Anderson \& Fujishima, 2021).

There are a few limitations to the study. Since survey administration happened while the students learned online because of the coronavirus pandemic, sentiments might have been colored by necessity. The students surveyed were from one university, and it would be interesting to determine if the feelings remain the same for students from a different setting. There should also be more research to see how strongly students feel about the various factors affecting the differences between video versus live presentations.

In conclusion, teachers need to be aware that there is a real fear of presenting in the live setting, lowered by video presentations. Students have the opportunity to improve their language through reflecting on their work and determining when the video presentation is ready for assessment. The motivation to turn in the best possible work and improve their score based on their effort is available to students. The other items that should be taken from the research are that having a clear rubric explained before the homework and posted so that students can see and understand is essential to the fairness of grading. Based on this, teachers should consider using student-produced video presentations once the classroom setting changes back after coronavirus restrictions are removed.

\section{REFERENCES}

Ahmad, N. A., \& Lidadun, B. P. (2017). Enhancing oral presentation skills through video presentation. PEOPLE: International Journal of Social Sciences, 3(2), 385-397. https://doi.org/10.20319/pijss.2017.32.385397

Amalia, N. L., \& Ma'mun, N. (2020). The anxiety of EFL students in presentation. ELITE Journal, 2(1), 65-84.

Anderson, L. M., \& Fujishima, C. S. (2021). Revising rubrics: Encouraging listener participation in online EFL presentations. Collection of Language and Literature Studies, 21(3), 15-30. https://doi.org/10.24510/00000505

Arifin, W. L. (2017). Psychological problems and challenge in EFL speaking classroom. Register Journal, 10(1), 2947. https://doi.org/10.18326/rgt.v10i1.29-47

Babaii, E., \& Adeh, A. (2019). One, two, ..., many: The outcomes of paired peer assessment, group peer assessment, and teacher assessment in EFL writing. Journal of Asia TEFL, 16(1), 53-66. https://doi.org/10.18823/asiatef1.2019.16.1.4.53 
Bandura, A. (1983). Self-efficacy determinants of anticipated fears and calamities. Journal of Personality and Social Psychology, 45(2), 464-469. https://doi.org/10.1037/0022-3514.45.2.464

Braun, V., \& Clarke, V. (2012). Thematic analysis. In H. Cooper, P. M. Camic, D. L. Long, A. T. Panter, D. Rindskopf, \& K. J. Sher (Eds.), APA handbook of research methods in psychology (Vol. 2, pp. 57-71). Washington DC: American Psychological Association. https://doi.org/10.1037/13620-004

Brookhart, S. M. (2018). Appropriate criteria: Key to effective rubrics. Frontiers in Education, 3(22), 1-12. https://doi.org/10.3389/feduc.2018.00022

Cowie, N., \& Sakui, K. (2018). Learning English through digital projects: A Japanese university case study. Osaka JALT Journal, 5, 20-43.

Dansieh, S. A., Owusu, E., \& Seidu, G. A. (2021). Glossophobia: The fear of public speaking in ESL students in Ghana. Language Teaching, 1(1), 22-35. https://doi.org/10.30560/lt.v1n1p22

Dellah, N. F., Zabidin, N., Nordin, N. A., Amanah, F. H., \& Atan, M. A. (2020). Glossophobia: Evaluating university students' speaking anxiety in English oral presentations. Jurnal ILMI, 10(1), 116-126.

Dörnyei, Z. (1994). Motivation and motivating in the foreign language classroom. The Modern Language Journal, 78(3), 273-284. https://doi.org/10.1111/j.1540-4781.1994.tb02042.x

Dörnyei, Z., \& Ushioda, E. (2021). Teaching and researching motivation. Harlow, England: Routledge. https://doi.org/10.4324/9781351006743

El-Garawany, M. S. M. (2017). The effect of vlogging on developing tour guidance students' EFL presentation skills and reflective thinking. Journal of Research in Curriculum Instruction and Educational Technology, 3(1), 4379. https://doi.org/10.21608/JRCIET.2017.24479

Fadlan, A. (2020). Factors causing language anxiety of EFL students in classroom presentation. ELS Journal on Interdisciplinary Studies in Humanities, 3(2), 219-230. https://doi.org/10.34050/els-jish.v3i2.9718

Grieve, R., Woodley, J., Hunt, S. E., \& McKay, A. (2021). Student fears of oral presentations and public speaking in higher education: A qualitative survey. Journal of Further and Higher Education, 45(9), 1-13. https://doi.org/10.1080/0309877X.2021.1948509

Hafner, C. A. (2014). Embedding digital literacies in English language teaching: Students' digital video projects as multimodal ensembles. TESOL Quarterly, 48(4), 655-685. https://doi.org/10.1002/tesq.138

Hallemans, N. (2021). Using student-created video presentations to build experiential learning in the oral EFL presentation classroom. Korean Journal of General Education, 15(5), 229-245. https://doi.org/10.46392/kjge.2021.15.5.229

Huang, H. W. (2021). Effects of smartphone-based collaborative vlog projects on EFL learners' speaking performance and learning engagement. Australasian Journal of Educational Technology, 37(6), 18-40. https://doi.org/10.14742/ajet.6623

Krashen, S. D. (2009). Principles and practice in second language acquisition. Retrieved from https://citeseerx.ist.psu.edu/viewdoc/download?doi=10.1.1.463.8762\&rep=rep1\&type=pdf

Kulsiri, S. (2018). Students' perceptions of a student-produced video project in the General English language course at Srinakharinwirot University, Thailand. Arab World English Journal (AWEJ) Special Issue on CALL, 4, 4054. https://doi.org/10.24093/awej/call4.4

Lee, Y. J. (2019). Integrating multimodal technologies with VARK strategies for learning and teaching EFL presentation: An investigation into learners' achievements and perceptions of the learning process. Australian Journal of Applied Linguistics, 2(1), 17-31. https://dx.doi.org/10.29140/ajal.v2n1.118

Lumsden, L. S. (1994). Student motivation to learn. ERIC Digest, 92, 1-7.

Mali, Y. C. G. (2018). Digital video presentation in an EFL writing classroom. Journal of Creative Practices in Language Learning and Teaching (CPLT), 6(2), 1-21.

Miskam, N. N., \& Saidalvi, A. (2020). Using video technology to improve oral presentation skills among undergraduate students: A systematic literature review. International Journal of Psychosocial Rehabilitation, 24(5), 5280-5291. https://doi.org/10.37200/IJPR/V24I5/PR2020235

Naqvi, S., \& Al Mahrooqi, R. (2016). ICT and language learning: A case study on student-created digital video projects. Journal of Cases on Information Technology (JCIT), 18(1), 49-64. https://doi.org/10.4018/JCIT.2016010104 
Santhi, D. D., Suherdi, D., \& Musthafa, B. (2019, October). ICT and project-based learning in a rural school: An EFL context. In A. Nurmandi, Y. Chen, N. A. Ismail, \& Z. Rafique (Eds.), Proceeding of Third International Conference on Sustainable Innovation-Humanity, Education and Social Sciences (IcoSIHESS 2019) (pp. 2935). Paris, France: Atlantis Press. https://doi.org/10.2991/icosihess-19.2019.5

Soifah, U., Jana, P., \& Pratolo, B. W. (2021). Unlocking digital literacy practices of EFL teachers. Journal of Physics: Conference Series, 1823(1), 1-10. https://doi.org/10.1088/1742-6596/1823/1/012030

Stanley, D., \& Zhang, Y. (2018). Student-produced videos can enhance engagement and learning in the online environment. Online Learning, 22(2), 5-26. https://doi.org/10.24059/olj.v22i2.1367

Sulastiani, S. (2020). Students' perception toward psychological problems faced in public speaking class. Journal La Edusci, 1(1), 33-39. https://doi.org/10.37899/journallaedusci.v1i1.46

Tuan, L. T. (2012). An empirical research into EFL learners' motivation. Theory \& Practice in Language Studies, 2(3), 430-439. https://doi.org/10.4304/tpls.2.3.430-439

Wallace, M. P. (2018). Fairness and justice in L2 classroom assessment: Perceptions from test takers. Journal of Asia TEFL, 15(4), 1051-1064. https://doi.org/10.18823/asiatefl.2018.15.4.11.1051

Yeh, H. C. (2018). Exploring the perceived benefits of the process of multimodal video making in developing multiliteracies. Language Learning \& Technology, 22(2), 28-37. https://doi.org/10125/44642

\section{APPENDIX 1}

Grading Rubric

\begin{tabular}{|c|c|c|c|c|c|c|}
\hline Grading Rubric Point & 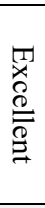 & $\begin{array}{l}\widehat{9} \\
\stackrel{2}{2} \\
0 \\
\vdots \\
2\end{array}$ & $\begin{array}{l}0 \\
8 \\
8\end{array}$ & 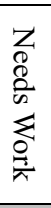 & 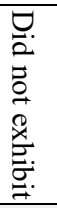 & Observed Behavior \\
\hline \multirow{4}{*}{ 1. Language } & 1 & & $1 / 2$ & & 0 & $\begin{array}{ll} & \text { Pronunciation } \\
\circ & \text { Intonation and stress }\end{array}$ \\
\hline & 2 & $1 \frac{1 / 2}{2}$ & 1 & $1 / 2$ & 0 & $\begin{array}{l}\circ \text { Word choice } \\
\circ \text { Reaching for words }\end{array}$ \\
\hline & 1 & & $1 / 2$ & & 0 & ○ Grammatical form \\
\hline & 2 & $1 \frac{1 / 2}{2}$ & 1 & $1 / 2$ & 0 & $\begin{array}{l}\text { ○ Understandability } \\
\circ \text { Too much Korean in presentation }\end{array}$ \\
\hline 2. Note Cards & 2 & $1 \frac{1 / 2}{2}$ & 1 & $1 / 2$ & 0 & $\begin{array}{l}\circ \text { Too big } \\
\circ \text { Holding with two hands } \\
\circ \text { Looking at too much } \\
\circ \text { Too many words }\end{array}$ \\
\hline 3. Eye Contact & 3 & $2 \frac{1}{2}$ & 2 & $11 / 2$ & 0 & $\begin{array}{l}\text { Looking away from people } \\
\circ \text { Closing eyes } \\
\circ \text { Reading from note cards } \\
\end{array}$ \\
\hline 4. Body Language & 2 & $1 \frac{1}{2}$ & 1 & $1 / 2$ & 0 & $\begin{array}{ll} & \text { Too stiff } \\
\circ & \text { Arms at sides } \\
\circ & \text { Bad posture } \\
\circ & \text { Nervous movements } \\
\circ & \text { Shifting around } \\
\end{array}$ \\
\hline 5. Gesture & 3 & $21 / 2$ & 2 & 1 & 0 & $\begin{array}{ll}\circ & \text { Too small } \\
\circ & \text { Not enough } \\
\circ & \text { Only hands } \\
\circ & \text { Not relevant }\end{array}$ \\
\hline 6. Opener & 2 & $1 \frac{1 / 2}{2}$ & 1 & $1 / 2$ & 0 & $\begin{array}{l}\text { D Did not introduce self. } \\
\text { Did not use one of the openers from book. } \\
\text { ○ It was not logical. } \\
\text { o It did not draw audience attention to topic. }\end{array}$ \\
\hline 7. Closer & 2 & $1 \frac{1}{2}$ & 1 & $1 / 2$ & 0 & $\begin{array}{l}\text { Did not use one of the closers from book. } \\
\text { O It was not logical. } \\
\text { o It did not draw audience attention to topic. } \\
\text { Did not thank people watching. }\end{array}$ \\
\hline
\end{tabular}




\begin{tabular}{|c|c|c|c|c|c|c|}
\hline 8. Content & 2 & $1 \frac{1}{2}$ & 1 & $1 / 2$ & 0 & $\begin{array}{l}\text { The presentation was on the assigned topic. } \\
\text { The material was relevant. } \\
\text { The material was logical. }\end{array}$ \\
\hline 9. Voice & 2 & $1 \frac{1}{2}$ & 1 & $1 / 2$ & 0 & $\begin{array}{l}\text { Too many fillers } \\
\text { Too quiet to be easily heard } \\
\text { Mumble or run words together }\end{array}$ \\
\hline 10. Power Point & 3 & $2 \frac{1}{2}$ & 2 & 1 & 0 & $\begin{array}{ll} & \text { Pictures too small } \\
\circ & \text { Too many words } \\
\circ \text { Pictures don't match words } \\
\circ \text { Looking at screen too much } \\
\circ \text { Words too small }\end{array}$ \\
\hline 11. Time: & 3 & \multicolumn{3}{|c|}{2 (+/- 5 seconds) } & & 0 (more than $+/-20$ seconds) \\
\hline
\end{tabular}

\section{APPENDIX 2}

\section{Survey Questions}

1. Do you perceive the grading of your online presentations as being fair? 온라인 프레젠테이션의 등급이 공정하다고 생각합니까?

2. Why or why not? 왜 그럴까요? 아니면 왜 아닐까요?

3. In your opinion, what elements most effect the fairness in grading live and online presentations? Be specific what you think affects each style. 당신이 생각하기에, 어떤 요소가 라이브와 온라인 프레젠테이션션을 채점하는 공정성에 가장 큰 영향을 미칩니까? 각 스타일?에 영향을 미친다고 생각되는 사항을 구체적으로 설명하세요.입니다. 